\title{
Allegory in Prison Letters: Art or Puzzle?
}

\author{
Bajram Kosumi \\ Rector of the Public University "Kadri Zeka" Gjilan, Republic of Kosovo
}

Copyright $(2017$ by authors, all rights reserved. Authors agree that this article remains permanently open access under the terms of the Creative Commons Attribution License 4.0 International License

\begin{abstract}
This article examines the style and discourse in prison epistles, a special literary manifestation in the Albanian literature of the late $20^{\text {th }}$ century. The allegoric and hermetic discourse dominates in these letters. Why does this happen: to hide the thoughts from the censorship of the prison administration (to disorient the censor, authors in general used many words with obscure meanings, and many other allegoric texts, which in reality are hypertexts) or simply for aesthetic and stylistic effects? This is a question which determines the status of the text. In this analysis special attention is given to words in the semantic and stylistic aspects. The focus of attention is especially allegoric and hermetic words and sentences. Decoding the words and sentences, of the allegoric and hermetic discourse, brings to a new light the text itself: whether it is a literary or a referential text. The stylistic analysis method and the critical discourse analysis are used in the examination. The critical discourse analysis is necessitated by the polysemy of the text, which lies always beyond the text and is interrelated with different textual or life contexts.
\end{abstract}

Keywords Documentary Literature, Prison Epistles, Allegory, Figure, Genre, Discourse, Style

\section{Introduction: Prison Letters, a Body of Literature at the End of the $20^{\text {th }}$ Century, and the Political Background}

From World War II to the demise of Yugoslavia, many Albanian intellectuals, mostly young men, were jailed and convicted to long-term prison sentences by the Yugoslav regime for their political activity for the freedom of Kosovo. These prisoners, especially after the 1981 revolution - the protest rallies of Kosovo Albanian pressing for republican status for Kosovo within the Yugoslav Federation - used all possible means necessary to convey to the public their political concepts, as well as their ethic, literary and humanist ideas from prison. As it has been observed, it seems they used this transmission of messages as a delivery for history and as a tool to preserve their soul and mind [1]. In this prison-history refraction one of the most valuable pearls in the Albanian literature, the prison literature, has been created. [2] It suffices to refer to some of the authors and their written work in prison to substantiate this claim: Merxhan Avdyli, Ismail Syla, Hydajet Hyseni, Visar Zhiti, Zyhdi Morava. In this interrelation between life, history and death, that body of literature which in Albanian is known as documentary literature, or as is known in the English culture, the non-fiction literature, has been created. Numerous prison diaries, prison memories, were written, but above all prison letters that have survived and triumphed (epistolary literature). This, for one administrative reason: prison administrators, every six months on average destroyed everything that the Albanians who had been jailed for political reasons had written. Only those letters that they managed to hide were saved, as well as epistolary literature. Families retained those letters (according to family members' accounts, they had nearly acquired the status of totem) and a small portion of them were edited and published by Merxhan Avdyli and Bajram Kosumi in 2004 in the anthological book entitled Letra nga burgu/Libri i censuruar [Prison Letters/ The Censured Book]. The editors of this book, in their job of classifying the letters for the book, had hundreds of other letters in their hands, part of which, in their judgment of high value, have not yet been published. This book serves as an invaluable depository for this article, as far as the discourse is concerned, i.e. the usage of a special linguistic code which is the allegoric expression. In view of the fact that these letters went through an administrative channel called censorship, the allegoric discourse seems necessary. This puts in doubt their literary value. The main question that this article aims to answer is whether the allegoric discourse in the prison letters, coupled with all other linguistic elements that engender this discourse, forms and its achievable models, are a desirable or a forced choice. More specifically:

1. Firstly, if the allegoric discourse is a case of the prevailing circumstances in which the letters had been written, and that the obscure and allegoric language had served only to hide the intended thoughts.

2. Secondly, if this discourse and language had served for esthetic purposes, meaning a purposeful usage of 
language so that communication yields also an esthetic function.

3. And thirdly, this discourse and language had served both purposes, to hide the thoughts of intended messages but also create an esthetic function.

If the first question of this hypothesis is proven, then literature does not have a reason to look after these letters. However, in case of the other two hypothetic questions, then literature must treat these letters as a matter of literature.

\section{Materials and Methods}

\section{a. Genre and Textual Structure}

The concept of epistolary literature is universally accepted in literary scholarship; likewise, the concept of the prison letters (Eng. The Prison Epistles, Letters from Prison). In the aspect of genre, prison letters, as a literary entity, date back to the Bible. In the tradition of Biblical commentary, this concept has a more accurate meaning [3]. Many scholars [4] acknowledge that some of Saint Paul's epistles, for example Epistle to the Ephesians, Epistle to the Colossians, Epistle to Philemon, and Epistle to the Philippians were written in the prisons of Rome, circa 60-62 [5] and were sent out via the visitors who had gone to visit Saint Paul in prison. Saint Paul starts his Epistle to Philemon the way prison letters have started for centuries:

"Paul, a prisoner for Christ Jesus, and Timothy our brother, to Philemon..."

And ends the letter thus:

"Epaphras, my fellow prisoner in Christ Jesus, greets you, as well as Mark, Aristarchus, Demas, and Luke, my co-workers" [6].

There is a similarity in this epistle/letter of Saint Paul, in genre, with the prison letters at the end of the $20^{\text {th }}$ century, written by Albanian political prisons. Therefore, there is no reason not to use the same concept, i.e. prison letters, for the Albanian literature too.

Prison letters have had the same form of genre and structure of text for the past two thousand years:

- an introduction that serves as a greeting/salutation (usually one to two paragraphs)

- the middle part (body) of the letter, where one or more topics are treated, and

- the final part of the letter which is used again as a greeting.

The first and the last part, thematically, are not very important, because they are discourse greetings and the language has a phatic function (according to R. Jacobson [7]), but in the semantic aspect, what kind of greetings are being sent is important for the study. Between these two parts, the introduction and the last part, the introductions are longer and richer thematically and stylistically:

"Mitrovicë, 5 January 1983

Good day, dad!

Firstly, I wish good health (to you) into the New Year now! Just a few days ago, I got a letter from you and understood that you are all well. I was really happy for that, as you will be happy from this letter of mine by virtue of which I inform you that I am in good health, with no troubles [8].

However, most of the time the introductory parts, though they look as a greeting discourse, or convey a personal feeling, serve as a formula to introduce various topics, and are organized according to the ethical Albanian code. Here is an example of how the personal thematic is associated discreetly with issues of public interest:

"Pozharevac, May 1990

Greetings to all!

I have not written to you for a long time, and I believe you assume why I have not written. Maybe the only reason why I have not written for such a long time is because what we have been going through has not been a time conducive to writing. I do not see any meaning in words at this time when, one way or another, everything is obvious, in the expectation of our fate being determined in general. As a matter of fact, our destiny (ill so far) has been decided so often in foreign offices and chancelleries, but all those decisions have been left on paper only, at a time when our truth is being written with blood, and on our skin, in our own land" [9].

Or else, introductions address directly a case, an account of various situations in terms of circumstances, human and spiritual, or simply being texts that relate an unfinished conversation started earlier and broken off (for example: in the letter I got from you, you wrote....; or: in the last letter I told you that...).

And the concluding parts of prison letters, the final part of the letter, is a greeting discourse, language with a phatic function, but in comparison with the introduction, this part is shorter:

"Pozharevac, 3.2.1985(...)

To Sahadete: I say to you only this: goodbye!

To Naim: Be a good boy!

Lots of hugs to Dritëro.

Greetings from my friends also.

\section{A. Zhitia" [10]}

Sometimes the concluding part is expressed in a single sentence: "Your sister Myrvete loves you so much". 


\section{b. Obscure, Allegoric and Elliptic Language}

Allegoric speech is so omnipresent in prison letters, making it so difficult to distinguish it from ordinary speech. So much so that this amounts to a literary predilection, meaning that the discourse aims to be always allegorical, even then when it has a referential function. Because of the censorship, on the one hand, and for literary reasons, on the other hand, allegory permeates all text and its meaning. Sometimes allegories are obvious, cliché (for example: the need for sunrays has always had allegoric meaning), but sometimes are too hermetic and very personal, and as such undecipherable for the average receiver. Talking about agriculture, planting, etc., one can convey a political message. If in a letter the mother says to Hydajet Hyseni that the village youth hoed corn for them, this should not simply be taken as merely concrete support in the agricultural field, but as news that youth of the village are following the political movement of their own people, prisoners. Berat Luzha talks to his mother, but one cannot be sure whether he is talking to the mother who gave birth to him, or to his homeland Kosovo:

"Awaiting, dear mother that one of your grandchildren that surrounds you when you tell them old stories, will inform you...And you eagerly expect the news of the return, that news of meeting, that piece of news which is left in anxiety. And, if I live to see that day, you have said, I will welcome death as well" [11].

These beautiful sentences are addressed to whom truly? To the mother, to Freedom, to Mother Kosovo, to Mother Albania, or to all of them at the same time?

In such discourse where the allegory is so dense that it sweeps the discourse altogether, the question to be posed rightly is if allegory is the figure and the desired type of discourse, or else an imposed figure and type of discourse. Allegory is the desired figure of modern literature which has a very powerful tradition in oral Albanian literature, especially in the colloquial style, which the prison letter is very close to, if not entirely part of it. On the other hand, writing in prison and going through a very vicious official censorship process, authors of prison letters had to hide the true meaning of their thoughts, or to encode the language so that the receiver can understand it but not the censor. Here is another factor which aided all this, a socio-linguistic fact: the sender and the receiver belonged to the same cultural-linguistic areal, whereas the censor most of the time was of a different cultural-linguistic areal because he/she had learned Albanian language as his second language. This fact facilitated the allegoric communication of prison letters, because many phraseologies and allegories easily understood by both sender and receiver were not detected by the censor. If we call upon the formula of communication according to the model of Klaudie Shanon and enriched by Warren Weaver (1947-49), then the censor plays two roles: one is the channel role (he/she can stop the letter, not send it to the receiver) and the second is the role of jamming which tends to prevent the communication between the sender and the receiver.

Having conducted a close analysis of prison letters, we have defined and classified some of the types of the allegoric discourse, which in some cases can be understood also as strategies of communication. The analysis of the types of the allegoric discourse, that is the analysis to understand how and in what form and what context is the allegoric discourse used, will help answering the question whether allegory was the desired or forced figure of the prison letter discourse. Two methods of analysis are of help to us here: 1) the stylistic method, through which we will distinguish words and sentences which in themselves have a secondary, figurative, meaning, especially allegories; 2) critical discourse analysis, through which we will understand contextual, cultural and wider reasons of the utilization of allegories and allegorical meaning in these letters. Likewise, obscure words and sentences, their meaning and reasons for their usage, will be analyzed.

\section{Results: Allegoric Types}

We have identified here several characteristic types of allegories, which do not belong to a standard typology, as in M. H. Abrams's A Glossary of Literary Terms (5) but we have rather identified them on the basis of the discourse and the context in which they were used. This leads us to a proper understanding of the role of allegory in prison letters. [12]

Allegory of the phatic function. Even though in the introductory parts of the letters language has a phatic function, i.e. it is used only to initiate a conversation, it often takes allegoric functions. This is how Ahmet Qeriqi starts his letter:

"Daddy's darling, I am writing with no hope that you will receive this letter because it looks they do not allow here letters written in the Albanian language, even though they do not acknowledge this openly" [13].

This sentence is not just a salutation, but also an attack on the linguistic and cultural policies of Yugoslavia against Albanians. Being in the phatic mode, this sentence does not sound very political, even though it is one, and it is written as a light allegory because of the censorship.

The intertextuality of the allegory. Prison letters abound in intertextuality, in all its forms as defined by Gerard Genette, Julia Kristeva, Natalie Piegay-Gros etc., [14]. Sometimes it is difficult to decode this intertextuality, sometimes it is easy to decode it; nevertheless, semantically it is hard to understand it. Here is an example, when Bajrush Xhemajli creates an obvious intertextuality, but with a high level of polysemy:

"When I arrived here, in this room, four months ago, when I parted with Bali [mode of addressing an elder brother or father in Albanian] and Shemi, they wanted to give me one of the calendars of 1989 , but I did not 
want it. I asked instead for the calendar of last year's "Kosovare" magazine, the one I had asked not to be removed from the wall at all because I loved it very much. My friends gave it to me very kindly. If you have seen it, you will certainly remember it: it features a young woman holding her child in her lap. (...) Under this picture, where months of the calendar appear, I had placed two photos: one is where the mother, Naza and you have had posed ("Mom, sister and wife together/ waiting on a straw-padded mattress on the divan"), and the other, is the one where you and mother posed. Beneath your photo is the map of the world, so you appear like having climbed over the earth, in the height of Olympus, to watch me over here" [15]

In this text the intertextuality is multiple:

- The letter in relation with the verses "Mother, sister and wife together// waiting on a straw-padded mattress on the divan";

- The letter in relation to the calendar and the two photos;

- Two photos in relation to the map of the world, and with the Olympus.

While allegory isutterly personal, and through it the author creates an epic situation: the wife and mother wait for him to get back from prison, she is beautiful and the author aims, wishes and seeks from her to create an entire world with children, once he is released from prison. As it can be seen, the allegory here is quite complex, but not for political or censorship reasons, but simply because of literary and linguistic reasons.

Allegory through humor. Virtually in all prison letters a humoristic discourse appears. This certainly requires an extra-literary explanation: how is it at all possible that from prison cells, where torture and other physical and mental suffering is present on a daily basis, we get letters with humor in them? This cannot be anything else but an allegory, in this case not for sender (the author) but for the receiver. Receivers are always the dearest people for the author, and should think a little bit like this: as long as he sounds funny, it must not be that horrible for him over there.

Allegory through animal nature. In one of the prison letters of Bajrush Xhemajli, birds are characters that act, and each one of them has an allegoric message:

"High-intensity raven calls awoke me very early. I realize I have had a good night's sleep, so I do not need more sleep. They always wake me up early, but I usually keep sleeping until the bell rings. On the other trees outside of the prison walls, there are always a lot of other birds. As far as one can see from here, the ravens have the upper hand. They dominate by their sheer number and by noise. There are so many of them that you get the idea that all the ravens of Pozharevc stay here. Maybe you noticed them too when you came to visit me. They can be seen from here: with their pitch black plume when they soar in the sky and darken it, by going up and down and screaming with their harsh calls.
When I see them like this, I recall the pleas of the valorous handsome man, fallen between the two snow-capped mountains: $O$ you ravens that are darkening/let my black eyes stay as they are/ so that I can see my mother, sister, wife/ to see my home is it still intact. (...)

Even though too many, the call of sparrows hardly reaches here through 37000 tiny holes of our window (approximately that is the number of holes in the metal net). Their voice is in this chorus of birds does not sound clearly in our ears. The big call the shots here the ravens. (...)

Not even the king of the song, the nightingale, with its sweet call, manages to change the melody of this tuneless chorus. Before the awful voice of the raven, his loveable voice is weak.

Be it as it may, his voice reaches as far as here, at least when during the course of the day the others get tired in this "race'. These tweets make me recite: O you little tiny nightingale, it is not your fault/ you do not know what is going on in here/seven vicious states have blocked us/ like in the great epic poems..." [16].

Allegory in this text is traditional: prison and the grillwork as a theatre of confrontation of ravens, sparrows and nightingales, wherein intertexts are intertwined, likewise allegorically.

An almost naked political allegory. At the time of the most intensive anti-Albanian cultural and political tensions in Serbia, this is how Gani Koci articulates this situation:

"Nish, 20.9.1987

My beloved

(...)

We are living and will be living for each other, and together we will live for the aspired dawn of freedom. Our hearts will forever beat at the same place for the same thing. (...)

Hard times are ahead of us. That is why, we must wait, and confront them as we should: strong and tough, like so far. We must know how to overcome them. Nothing should break or confuse neither us nor you. With mutual faith and full support, we will prevail and we will triumph. So have faith and stay strong with dignity" [17].

Koci's text is allegoric, because he calls for strength and faith in the face of the ever strengthening storms gathering around Kosovo, but it is so overt that it can be called a naked allegory.

Personal discourse as a public discourse. Very often public discourses are inserted into prison letters, posing as family and personal texts. For example, this is how Jakup Krasniqi composes such a text: 
"Brothers, an unprecedented enthusiasm has overwhelmed us. It is good that there is enthusiasm, but we should not rest on our laurels. We had done a lot already, but a lot of work lies ahead of us" [18].

The personal discourse as an allegory of philosophical discourse. Januz Januzaj writes his letters with a philosophical discourse. His words are deep, have a deep meaning, and are elliptic and honorable, in the style of Nietzsche, as wise words and proverbs:

"Mother, I do not expect any letters from you. You have already written everything, a long time ago. You have said the rights and the wrongs: woe unto him who cannot see them! Veins in your hands, wrinkles in your forehead, your stooping body, the bones that bespeak of life, are not your last signs; you were born with them.

You and I do not have what to say to one another. When your soul falls asleep, mine does as well; when your soul walks, so does mine. If you have decided "to go" to the other world, go! You are in me. You will only be in debt to me for a walk on foot to the uncles.

Nothing else.

Holding you tight and hugging you, Januzi" [19].

Encouraging personal-public allegory. Merxhan Avdyli uses an allegory which creates a connection between what is personal and public. He talks about the personal but actually aims the public:

"Today I have done 6 years and 4 months in prison and in two months I will end half of my prison term. Fair enough. Days are elapsing in this manner as well, and actually it seems to me, (maybe also to many others), for the time being it is better that I am in prison (for some reasons, of course) rather than being out, because, for what I am reading in the press and seeing on TV, I would not be able to close my eyes and ears and ultimately my mouth. So, prison is the best place to think about what is dear to your heart because it cannot get worse for a person than being in prison. Therefore, the only freedom I have got in prison is the freedom of thought. I do not know how things are outside, but for what I can learn from press and TV reports, I feel sorry for those who can endure, but this is how time brings along some moments, when one must be patient and endure the heat of this sizzling summer day, or one's head in the refrigerator when it is freezing cold" [20].

As for the political identification in this text, it is very clear and not hidden. Hidden and allegorical here is the game with the prison as a place where one can think freely. So, an utterly beautiful allegorical style of discourse.

Allegory as an irony. All the letters speak of the cruel regime in Yugoslav prisons, especially against the Albanian political prisoners, and this is the most common topic. Merxhan Avdyli generated a unique allegorical discourse on this topic: he writes allegory with anti-allegory. Or else: he acts like he is using allegory, but in fact he only uncovers his allegory and, by doing so, he creates a good discursive effect:

"Pozharevc, on 8 November 1987, Sunday

Greetings dear father Nazmi!

This time I am addressing you personally.

During your last visit here, you understood that I was in solitary confinement. I came out of it yesterday. I was into solitary confinement for 30 days. To tell you why I was in solitary confinement is not ' $\mathrm{OK}$ ', because I was not the only one, and if I told you now the letter might be shredded. Therefore, shush! I am killing the truth so the letter survives. I can only tell you this as far as the solitary confinement is concerned: the cells where the solitary confinement is served out are two and a half meters underground. The electric lamp is on all day, because otherwise you can only poke your fingers in your eyes. You have no right to read, not even to write letters there. Even there, however, you enjoy, rights such as: besides food and sleep, you have the right to breathe, as little chance as you stand of doing this; further on, you enjoy the right to think anything you want, (of course not loudly). Finally, you have one more vital right, very valuable, that nobody can deny you butt before I mention it I need to apologize for the expression, so: it is not forbidden to urinate and defecate!

Daddy, you know the saying, "a dog does not eat a fellow dog". But I am saying that a man eats a man, even with clothes on. As to when will a human being become a human being nobody knows, but for a long time to come certainly not. Therefore, in order to preserve my integrity, I will have to leave it at that!" [21].

In this text two types of discourses, ironic and allegoric, can be clearly noticed. The allegory is deciphered at the defeat, ignorance, irony etc. with the viciousness of the prison. For nothing has Merxhan been sentenced to 30 days in solitary confinement, he comes out of it and smears that regime and that. Irony seals allegory: those who do that violence, they are surely not human, but nobody knows if they will ever be.

What is of interest for our analysis here, allegory is at the service of effective and beautiful expressive power; it is language that is opted for, not imposed.

Allegory as a dream. Shaban Shala has chosen the dream to convey his political and personal messages. The dream serves him as a foggy cover, as an allegory, maybe to confuse the censor (this guy talks about dreams! It cannot therefore be dangerous!) and also express his vision more beautifully and effectively. He writes a letter to his wife, where he tells her about the dream he had had, and where in that dream he describes himself very realistically, his activity, his love for 
his wife and their child, describing the "wild beast" that rises and grabs Shaban, who tries to protect himself fighting with his bare hands, while his wife cries and threatens the beast, but "the slobbering beast was taking me towards its cage." From the cries and tears three rivers are created which unite to create a sea: for the beast and its offspring the sea was death, because they drown in the sea of tears, but the same sea holds Shaban floating on the surface, until finally evaporating and producing a rainbow of victory [22].

The conclusion that Shaban Shala gives to his dream is of a fairytale type, but an easily decodable allegory.

Allegory as a disguise. The composition of poems in the form of prison letters, that is disguising them, is a common phenomenon in these letters. Pjetër Arbnori had gone further with the disguise of the real original literature: he wrote the novel Brajtoni, një vetëtimë e largët [Brighton, a thunder far away] in the prison of Burrel (Albania) in 1965, published in 2000 , by disfiguring entirely the world of his novel: the plot, the characters and the time are set in Ireland and England; instead of putting his name to the novel he put the name of a supposed English writer, while saying to the prison guards that he was translating a novel from English into Albanian. Arbnori had used this ploy with more than one of his books. [23].

Similarly, many prison letters start with the first usual paragraph, as a greeting, to only be continued afterwards with poems, but posing as prose fiction (seemingly a prison letter) or continued as an essay, a story, or another genre, but always disguised as prison letters.

\section{Conclusions: Allegoric Discourse, Art or Puzzle?}

At the beginning of the paper we posed the question whether allegory is the figure and the desired type of discourse, or the figure and the imposed type of discourse. We can now further specify the question thus: whether the allegoric discourse, in all the analyzed types and definitions, has served to convey a message of art, whether it has served literary purposes, or else has served to conceal and blur the message in order to create the puzzle?

When Merxhan Avdyli structures his letter in a way which affirms by denying (for example: I do not want to say that I have been in solitary confinement...) and props up the paradoxical nature of this discourse, he certainly utilizes allegory mainly to engender expressiveness and literary effects. But, when Hydajet Hyseni writes to his family asking them to enquire whether village youth want to assist the family to hoe the corn, of course this is an allegory of the puzzle type. If the young people of the village would come to assist with hoeing the cornfields of Hydajet Hyseni's household, the message was that they were in solidarity with the ideology and activity of Hydajet Hyseni, and vice versa.

Allegoric discourse in prison letters is one of the creative principles of these texts. It is profound and universal, interrelated with other types of discourse that very often makes it hard to differentiate. The very list of books that have been read, the very requests of books to be purchased, the simplest description of the prison's room has allegorical effects. This should in no way mean that allegory is the dominant feature of prison letters. On the contrary: often times the discourse of the prison letter is overt and referential.

There is no other cultural, intellectual or social situation in Kosovo of that time, or in the Albanian space as a whole, and there are no Albanian texts written which would speak so openly, bravely (and allegorically) about real cultural, political, social, linguistic and ethical developments especially in the Albanian society, but even beyond, as much as in the prison letters. These prison letters are the purest monument to the courageous Albanian thinking in the last two decades of dictatorship in the twentieth century. Only from this aspect we can understand how unhappy Albanian political prisoners, authors of prison letters and from a larger literary entity, were with all that was being written at that time in Albanian language, in the media and to a degree in literature as well. Only in view of the meaning, the topics, allegories, and the referential texts, that is overtly open, prison letters that went through official censorship by the Yugoslav state, we can understand the despair of Basri Musmurati when he says:

"Our scribblers, down in Kosovo, have been writing hymns to everyone, but not to their own selves. I would feel they are dead in this sense, if I had not read some interviews in newspapers by a single academic of ours, or even by an odd journalist" [24].

This fact in itself suffices to conclude that besides the need to conceal the thinking because of the censorship, the allegoric discourse was used generally for literary effects. If in the many parts of the text we come across a lot of paragraphs which openly express political concepts punishable by the state, and which censors had read, why then in some other parts of the text thoughts are expressed with allegories? The answer must lie in the art(fullness) of these letters. It was not, therefore, the ultimate purpose of the prison letters' authors to hide or conceal their real thoughts, because they ask from others also to expose their thoughts more openly. It is when they speak in prison letters specifically about political matters, which were on the censors' target, that they are more open. However, when talking about other topics, many times personal ones, like love, allegory is used. The imposed allegory is a form of existence of these texts, but in general allegory is a choice by the authors and these texts outlive as literary allegories. Virtually in all the allegorical models in these texts, such as the allegory of the phatic function, the allegory of intertextuality, allegory through humor, allegory through animal nature, the virtually naked political allegory, personal discourse as an allegory of the public discourse, personal discourse as an allegory of the philosophical discourse, the 
incentive personal-public allegory, allegory as an irony and allegory as a dream, the allegoric discourse is used as an esthetic and literary requirement of the language, and not merely as an existential condition. Finally, the allegoric discourse in these letters ferments the texts with the esthetic function of the language, and, as such, merits due scholarly treatment by literary historians.

\section{REFERENCES}

[1] Claassen, "Living in a place called exile: The universals of the alienation caused by isolation", Literator 24(3) Nov. 2003, pp. 85-111. See and: Kosumi, Bajram, Letërsia nga burgu/kapitull $i$ vecantë në letërsinë shqipe [Prison literature / separate chapter in Albanian literature], publishing House Toena, Prishtinë, 2006.

[2] Kosumi, Bajram, "Letërsia nga burgu/ cështje të identifikimit, definimit dhe të trajtimit të saj" [Prison literature/ issue of identification, definition and its treatment", lecture at the XXX International Seminar for Albanian Language, Literature and Culture, Pristina, on 15-27 August 2011. See B. Gjoka, "Literature from prison - trace values in this literary circle", http:/uni-gjilan.net/wp-content/uploads/2015/12/Behar-Gjok a.pdf

[3] See: W. E. Mills \& E. V. McKnight \& R. A. Bullard. Mercer Dictionary of the Bible, Mercer University Press, 2001, p. 713.

[4] D. Hamm, SJ. Philippians, Colossians, Philemon: Published by Baker Academic, 2013.

[5] G. Taylor. The Prison Epistles of the Apostle Paul/ Ephesians, Colossians, Philippians, Philemon, http://www.centervilleroad.com/. B. Utley. Paul Bound, the Gospel Unbound: Letters from Prison (Colossians, Ephesians and Philemon, then later, Philippians), 1998.

[6] B. Utley. Paul Bound, The Gospel Unbound: Letters from Prison (Colossians, Ephesians and Philemon, then later, Philippians), 1998 (translation from Serbian language in: www.Poslanice iz zatvora - Free Bible Commentary, p. 128).

[7] Bible. Letter to Philemon, 1 and 23.

[8] R. Jakobson. "Closing Statement: Linguistics and Poetics", in Conference on Style (1958: Indiana University) and Sebeok, Thomas A., editor, Style in language, Technology Press of MIT (Cambridge), 1960.

[9] M. Avdyli, \& B. Kosumi, Letra nga burgu/ libër i censuruar, [Prison Epistle / censored book], Brezi '81, Prishtinë, 2004. p. 369.

[10] Avdyli, \& B. Kosumi, Letra nga burgu/ libër i censuruar,
[Prison Epistle / censored book], Brezi '81, Prishtinë, 2004. p. 323.

[11] Avdyli, \& B. Kosumi, Letra nga burgu/ libër i censuruar, [Prison Epistle / censored book], Brezi '81, Prishtinë, 2004. p. 36.

[12] Avdyli, \& B. Kosumi, Letra nga burgu/ libër i censuruar, [Prison Epistle / censored book], Brezi '81, Prishtinë, 2004. p. 113.

[13] Abrams, M. H., A Glossary of Literary Terms, seventh edition, Heinle\&Heinle, Thomson Learning, 1999.

[14] M. Avdyli, \& B. Kosumi, Letra nga burgu/ libër i censuruar, [Prison Epistle / censored book], Brezi '81, Prishtinë, 2004. p. 52.

[15] Natalie Piegay-Gros. Poetika e intertekstualitetit, [Poetics of intertextuality], Parnas, 2011, p. 23 etc.

[16] M. Avdyli, \& B. Kosumi, Letra nga burgu/ libër i censuruar, [Prison Epistle / censored book], Brezi '81, Prishtinë, 2004. p. 96.

[17] M. Avdyli, \& B. Kosumi, Letra nga burgu/ libër i censuruar, [Prison Epistle / censored book], Brezi '81, Prishtinë, 2004. p. 97.

[18] M. Avdyli, \& B. Kosumi, Letra nga burgu/ libër i censuruar, [Prison Epistle / censored book], Brezi '81, Prishtinë, 2004. p. 160-161.

[19] M. Avdyli, \& B. Kosumi, Letra nga burgu/ libër i censuruar, [Prison Epistle / censored book], Brezi '81, Prishtinë, 2004. p. 248.

[20] M. Avdyli, \& B. Kosumi, Letra nga burgu/ libër i censuruar, [Prison Epistle / censored book], Brezi '81, Prishtinë, 2004. p. 263.

[21] M. Avdyli, \& B. Kosumi, Letra nga burgu/ libër i censuruar, [Prison Epistle / censored book], Brezi '81, Prishtinë, 2004. p. 309-310.

[22] M. Avdyli, \& B. Kosumi, Letra nga burgu/ libër i censuruar, [Prison Epistle / censored book], Brezi '81, Prishtinë, 2004. p. 310.

[23] M. Avdyli, \& B. Kosumi, Letra nga burgu/ libër i censuruar, [Prison Epistle / censored book], Brezi '81, Prishtinë, 2004. p. 440-441.

[24] Çefa , Interview with writer, Pjetër Arbnori, http://albanovaonline.info/index2.php?option=com_content\& do_pdf $=1 \&$ id $=238$

[25] M. Avdyli, \& B. Kosumi, Letra nga burgu/ libër i censuruar, [Prison Epistle / censored book], Brezi '81, Prishtinë, 2004. p. 109. 